\title{
COLLECTIVE COMPETENCIES AND STRATEGIC PEOPLE MANAGEMENT: A STUDY CARRIED OUT IN FEDERAL PUBLIC ORGANIZATIONS
}

KELLY WEIRES RODRIGUES SOARES AVELINO

Fundação Getúlio Vargas (FGV), Rio de Janeiro - RJ, Brazil.

DENISE MEDEIROS RIBEIRO SALLES

Universidade Federal Fluminense (UFF), Niterói - RJ, Brazil.

ISABEL DE SÁ AFFONSO DA COSTA

Universidade Estácio de Sá, Rio de Janeiro - RJ, Brazil.

To cite this paper: Avelino, K. W. R. S., Salles, D. M. R., \& Costa, I. S. A (2017). Collective competencies and strategic people management: a study carried out in federal public organizations. Revista de Administração Mackenzie, 18(5), 202-228. doi 10.1590/1678-69712017/administracao. v18n5p202-228 


\section{ABSTRACT}

Purpose: To identify whether public organizations that adopt the competency-based management model consider the collective component of competencies in their management practices.

Originality/value: The academic literature highlights the potential of collective competencies to achieve organizational objectives, but there is a mismatch between the theoretical perspective and people management practices, which was confirmed throughout the study.

Design/methodology/approach: The field research was carried out in three federal public organizations. Evidence was collected from documentary analysis and semi-structured interviews with ten employees from the respective Personnel Management areas.

Findings: There was an isolated presence of attributes and sources of creation of collective competencies, which proved to be insufficient to determine their presence in the organizations under analysis.

\section{KEYWORDS}

Public management. Management models. Strategic human resource management. Competency-based management model. Collective competency.

\section{INTRODUCTION}

The business scenario presents an ongoing process of change and renewal. The competitive environment has been forcing companies to take increasingly strategic actions that focus on the development of products and services that meet market demands. Furthermore, strategies and practices in the field of public administration have been redirected to meet the complex demands of society. 
Thus, in the public administration, a transition from the conceptions of what generates the strategic differential is perceived, considering the intellectual capital of the organization as a true ally in the process of generating organizational effectiveness (Bergue, 2014).

This perspective is reflected in a notable change in the role of people management, which departs from a bureaucratic and operational performance to a strategic one, gathering efforts, techniques and tools of human factor management to achieve organizational objectives. This conception serves as a basis for strategic people management, which can be understood as a systemic alignment of HR practices with the strategy of the organization, providing cohesion to the set of adopted practices. Among these practices, the competency-based strategic management model, which is the focus of this study, is highlighted in discussions regarding contemporary people management (Carbone, Brandão, Leite, \& Vilhena, 2009; Fernandes, 2013).

The competency-based strategic management model allows for the use of people management efforts to plan, capture, develop, and evaluate the competencies that are necessary to meet organizational objectives at the different levels of the organization (individual, group and organizational levels). Therefore, the competency-based management model is aligned with the strategic people management, for it is committed to the development of the competencies that are necessary to meet the strategic objectives of the organization. The competency-based management model is a practice that aims to increase the overall performance of the corporation, whether public or private, by increasing the individual performance of its employees.

In the Federal Public Administration, such discussion has acquired significant contours since the publication of Decree No. 5.707/06, which established the Competency-Based Management System as one of the instruments of the National Policy for Personnel Development - PNDP.

When seeking an alignment with modern people management practices, the federal public administration assumes that there is an urgent need to modernize its practices. This orientation raises questions about the real applicability of such management model in the reality of the Brazilian public administration when the specificities of the public sector are taken into account.

The PNDP, in much the same way as in the private sector, focuses on individual competencies. It thus replicates the individualized logic of organizational performance and results, putting the social, cultural, and political dynamics of the organization in the background.

The competency-based management model assumes that organizational competencies guide the actions that permeate management subsystems - 
and among them, people management. However, the emphasis placed on individual competencies by organizations raises questions about the extent to which organizations can articulate the elements of the management model to their full potential or if they use only random practices and tools, thus compromising the proposed strategic effect.

These arguments are consolidated as a growing academic development is perceived regarding the collective component of competencies - a factor that is still ignored in the practice of organizations, whose focus is restricted to individual and organizational skills. In spite of the fact that "organization" refers to a collectivity - the organizational system - there is a flagrant disregard for factors that emerge from collective work practices, that is, from interactions between groups - an intermediate class between the individual and the organizational level (Defelix, Le Boulaire, Monties, \& Picq, 2014; Lima \& Silva, 2015; Silva, 2013; Silva \& Ruas, 2016).

Now, knowing that the aspects of organizational culture can influence individual behavior, that the organizational climate brings an impact on the daily life of the organization, and that the constitution of effective work teams can contribute to increase productivity at work, why should so much emphasis be placed on the contributions of the individual to the organization?

The gap between organizational discourse, which advocates teamwork, cooperation between peers and sectors of the organization, and management practices, which focus on the individual, reveals an organizational daily life marked by contradictions and polarities.

This study is aligned with the understanding that the functioning of the organization is a result of collective work practices, not only by the sum of individual actions, but also by the association between individuals, areas and functions that serve as a basis for organizational outcomes and results. The question that it attempts to answer is the following: do public organizations that adopt the competency-based strategic management model consider the collective component of competencies in their management practices?

To answer that question, a qualitative study was carried out in three federal public organizations: Federal University of Pará (UFPA), Federal University of Paraíba (UFPB) and the National Treasury Secretariat (STN). Representatives of people management areas of these institutions were interviewed. Considering that the phenomenon under study is associated with a specific combination of factors and directly related to the context for its development, the attempt was to identify situational characteristics concerning the organizational realities under study, in order to contribute to the vastness of data and subsequent comparison. 


\section{PROBLEMATIZING PEOPLE MANAGEMENT IN THE BRAZILIAN PUBLIC ADMINISTRATION AND THE INTRODUCTION OF THE COMPETENCY- BASED STRATEGIC MANAGEMENT MODEL}

The context of rapid changes in the current scenario, marked by the development of new technologies and frequent innovations, generates the need for organizations to respond with agility and efficiency. The public sector is not exempt from this process, and its adaptation to the context of multiple transformations is increasingly required (Bergue, 2014).

The 1980s are cited by Fonseca, Meneses, Silva and Campos (2013) as a significant time in terms of the transformations fostered in public administration in several countries, a time which was marked by the modernization of the public sector and the change in the role of the State. In the specific case of Brazil, the authors mention that the state reforms followed the managerial perspective according to which management practices prevailing in the private sector were taken as reference and transposed to the public sector in order to promote greater efficiency in the state administration and focus on results.

In this context, attempts to innovate the public administration mean the search for efficiency and quality for the provision of a quality public service and, in order for that to be possible, it would be necessary to introduce a new management culture and, consequently, a rupture with the traditional management model (Guimarães, 2000).

Focusing on people management in the Brazilian administration, Schikmann (2010) states that substantive transformations in public administration would not be feasible if historical aspects were to be left aside. The combination of components such as the legalistic and formal culture in the public administration, cultural traits such as patrimonial assets and individualism when "contrasted with the idealized attributes of professional bureaucracy such as impersonality and merit" will result in a complex environment for people management (Schikmann, 2010, p. 12).

It should be noted that a fundamental aspect of the Brazilian public sector management is the presence of two functional bodies with distinct characteristics: a permanent body and a transitory body. The permanent body is formed by career employees who are hired after they go through public exams and, for Pires and Macêdo (2006, p. 97), "their goals and culture were formed within the organization". The transitory body, however, is formed, 
for the most part, by workers in commissioned positions and at managerial level. The occupation of these positions follows, as a matter of priority, the logic of political nomination, and there is, in practice, a strong rotation of the people in these positions after each succession of political administrations. The occupation of managerial levels by transient personnel is at the root of the difficulty of forming a merit-based bureaucracy, according to the models defined by managerial premises (D'Araújo, 2007; Monteiro, 2013).

The observed effects of administrative discontinuity are the interruption and duplication of projects and teams, short-term perspectives, lack of professionalism due to nominations without merit-based criteria as well as the conflict of interests and objectives between teams and leadership (Pires \& Macêdo, 2006).

Similarly, Amaral (2006) argues that the Brazilian public administration has historically constructed peculiarities and highlights three dimensions that would contribute to the understanding of these characteristics: the hybrid model of public servants' careers, which is a consequence of the alternation of projects throughout the administration; the type of Brazilian Federalism, which emphasizes the autonomy of the powers and the consequent existence of statutes of servants and ways to define permanent workforce and positions of trust, which are distinct in each of the spheres of the government and federated entities, generating disparity of rights, wages and requirements for taking a public office, and the environment in which the administration operates, where social and economic heterogeneity prevails.

These aspects portray different faces of the Brazilian public administration and generate direct implications for People Management in public organizations. Moreover, according to Schikmann (2010), many of these organizations would keep working with the management of personnel rather than with people management itself; that is, activities related to payroll, benefits, proposition of laws, rules, regulations and actions of training and qualification would be the focus of operations. Far from having a strategic role, HR operations would still be reactive, meeting operational demands and having a strong impact on the adoption and introduction of new policies and management tools. The necessary adjustment of the State to modernization demands requires changes in the public service culture and large-scale actions in order for a strategic operation to be implemented (Bergue, 2014).

In this scenario, the PNDP, instituted by the Federal Government through Decree No. 5707/06, explains the search for constitutional transformation and the promotion of changes in the area of people management (Schikmann, 
2010; Amaral, 2006). According to Amaral (2006), the new policy is in line with modern people management, which would be based on the strategic tripod: management by competencies, democratization of labor relations that foster environments conducive to innovation, and intensive qualification of work teams. That way, the new policy of people training and development would hold this strategic vision when promoting competency-based management as necessary to the public administration.

However, the Decree alone does not represent the reality of public organizations; it represents the initiative and the establishment of guidelines for its implementation within the federal administration. Despite the strong strategic component in its elaboration, there is still a long way to go until actions are effectively implemented and results can be duly observed in the public sphere as a whole.

Nevertheless, the initiatives to adapt to the PNDP are increasing and growing stronger as public institutions begin to discuss and publicize the effects of the implementation of the competency-based model for people management. Theoretical contributions and case reports become more representative, revealing the increase in the variety of public organizations that already use or are attempting to implement this model.

\section{THE COMPETENCY-BASED MANAGEMENT MODEL}

The competency-based management model considers the participation of employees as a fundamental aspect to the implementation of the organizational strategy and the development of competitive advantage. Ruas (2005) and Silva and Mello (2011) point out that socioeconomic factors such as economic instability, low predictability of the company-market and company-client relationship, besides the intensification of customization strategies generate new forms of work organization, transitioning from stability and predictability to a differentiated and fluid condition. These factors are conducive to the construction and use of the competency notion. Siqueira (2006), however, argues that the development of new forms of management is based on a flexible organizational structure and a better adaptation to the external environment.

It is in the above-mentioned context that the discussions about the notion of competency are strengthened and propagated; such discussions are marked by controversies and great conceptual heterogeneity, and even theoretical fragmentation. 
Guimarães (2000) presents three views that contribute to a better understanding of the different uses and developments in the approach to competency in the world of work. The author considers the first view as that of strategic management, related to the application of the concept at the macro level of management, whose essential competencies would be at the core of the discussions. The second would be related to human resource management and its use in the integration of people management subsystems. The third would be related to the sociology of education and work, with emphasis on psychosocial aspects and effects on educational and qualification programs.

The association of the first two perspectives seems to better represent the current conception of the competency-based model, thus integrating the strategic conception to the people management operation, serving as the basis for the strategic people management (Comini, Konuma \& Santos, 2008; Ruas, 2005; Silva \& Mello, 2011).

Fonseca et al. (2013) reinforce the strategic conception of this model by considering, in addition to the vertical alignment, the horizontal alignment. It is vertical insofar as the organizational strategy serves as a subsidy for the definition of organizational competencies that, in turn, would be deployed in individual competencies. It is horizontal when the alignment of the people management subsystems is considered.

\section{COLleCTIVE COMPETENCIES}

The perspective that is gaining momentum in the current discussions about competencies is that of collective competencies. As highlighted by Silva and Ruas (2016), the interest in collective competencies arises from studies associated with the Resource Based Vision (RBV) theories that highlight the role of work collectives in organizational performance, developed from Nelson and Winter's (1982) seminal work on Organizational Routines (OR).

Silva and Ruas (2016, p. 256) argue that collective competencies are based on the notion of collective work configurations, understood as "the work configurations in which collective action supplants individual action; that is, individual work must follow the determinations of collective work." In other words, it refers to the participation and interaction of individuals in work groups; individual work is subjected to organizational norms, context of assignments and work processes, among other aspects. Thus, 
the collective competency is defined as an intermediate component in the functioning of organizations; it is placed between individual competencies at the micro level and organizational competencies at the macro level.

According to Silva and Ruas (2016), four theoretical perspectives serve as reference for the analysis of the collective dimension: concepts of collective practices, from the perspective of Organizational Routines (Michaux, 2011; Nelson \& Winter, 1982); different forms of sharing, cooperation, interaction and socialization of work and individual expectations (Frohm, 2002; Sandberg, 1996; Zarifian, 2001); management policies capable of mobilizing the cooperation and interaction of individual work (Pauvers \& Schieb-bienfait, 2011); and the attributes of collective competencies (Retour \& Krohmer, 2011).

Eminent authors such as Prahalad and Hamel (1990), Le Boterf (2003), and Boreham (2004) should be cited because they approach competency through a comprehensive perspective, that is, the collective view, be it from the organizational perspective (Prahalad \& Hamel, 1990) or from the group work perspective (Le Boterf, 2003; Boreham, 2004; Zarifian, 2001).

In line with the authors mentioned above, Ruas (2005) associates the notion of competency with the socioeconomic scenario and the concept of event. For the author, the collective competencies could refer to a single area of the company, to several areas, to the company as a whole and also to activities between different companies. In terms of scope, there would be individual competencies, functional competencies (by groups or areas) and organizational competencies (Lima \& Silva, 2015).

An important contribution to the debate on the subject is attributed to Le Boterf. The author emphasizes the complexity of the topic and states that the competency of a company or its sectors is not limited to the simple sum of the competencies of its members. More than that, it is a result of the combination, cooperation and synergy of individual competencies (Le Boterf, 2003). In this perspective, collective competency would be a network competency, marked by the articulation of individual competencies, or the result of a collective interactive action based on individual competencies, with common objectives, that is, collective competencies would result from collective articulations and synergy of the group in work situations (Fontoura, Avila, Corsetti, \& Ruas, 2011).

Michaux (2011) states that the concepts of individual, collective and organizational competency are related to different theoretical views, but that the combination of these concepts would allow for the discussion 
of the existence of a collective capacity within organizations that could help coordination, collective solution of problems, and integration of knowledge and practical knowledge that would be linked to collective performance.

The concept of collective competency is comprehensive; it brings together different cognitive and social (cooperative) phenomena, which would help the capacity to act and react collectively. According to Michaux (2011), the action deserves to be highlighted because the concept of competency has a dynamic character and involves the mobilization of resources in order to act. The very use of the term competency, when referring to this collective capacity, allows to privilege the productive potential of this social phenomenon, as well as to highlight the respective contribution to the capacity of organizations to maintain and manage collective performance (Michaux, 2011; Silva \& Ruas, 2016).

The collective competency is then related to the different work groups and social configurations within organizations. This ability to act collectively would be of a tacit nature and not possible to be replicated since the combination of factors would particularly belong to each collective body, to each organization (Grimand, 2011; Michaux, 2011). Michaux (2011) highlights four contexts of use of the notion of collective competency: 1. dynamics and team results; 2 . collective learning; 3 . sharing of knowledge and experiences, and 4. cooperation of communication.

In a similar vein, Retour and Krohmer (2011) discuss the existence of different sources for the creation of collective competencies, distinguishing aspects related to people (individual competencies, affective interactions, informal relationships, and cooperation) and aspects related to the organization (configuration of work groups, formal interactions, management style, and factors associated with people management practices). The authors argue that collective memory, common referential, shared language, and subjective engagement are constituent elements of collective competency (Retour \& Krohmer, 2011; Silva, 2013).

The complexity of group production and the articulation of individual knowledge towards a common goal make collective competency a highly relevant subject for people management, especially in the complex context of contemporary work. The understanding of these intermediate collectivities, between the individual and the organizational system, presents itself with strong potential for the understanding of the organizational dynamics and, especially, for people management. 


\section{METHODOLOGY}

As a research strategy, the qualitative approach was chosen, aiming to deepen the phenomenon in question in the respective field of study: two Federal Institutions of Higher Education (IFES), UFPA and UFPB, as well as an organization of the Federal Financial Administration System - the STN.

The selected organizations met the initial criterion of the use of a competency-based management model in their practices of people management and, additionally, the representativeness in the implementation of such model. When it was impossible to verify the appropriation of the competency-based management model throughout the organization, the areas directly related to the implementation of personnel management were chosen for the fieldwork.

The analysis of the three realities and their respective peculiarities contributed to the richness of the data and subsequent establishment of comparative relations.

The data was collected from documentary analysis, from information provided by organizations as well as from public data such as plans, decrees and others. Semi-structured interviews were also carried out with the employees of the personnel management departments in order to identify how organizational practices were articulated with the organizational competencies outlined a priori - through the strategic planning of the organization and survey of the perceptions of the employees on the factors conducive to the emergence of collective competencies.

The interview script was developed based on the investigations carried out by Silva (2013) on HR management practices and the process of identification of collective competencies implemented in a credit service cooperative; by Giansante (2013) on the relationships between the characteristics of team members, collective competencies and collective performance in a gastronomy technology course, and by Retour and Krohmer (2011), regarding the components and variables conducive to the emergence of collective competencies and attributes and sources that influence their development.

Eighteen items were developed and grouped into six themes: 1. the competency-based management model; 2 . attributes of collective competencies; 3. sources of creation of collective competencies; 4. presence of collective competencies; 5 . factors mobilizing collective competencies associated with 
practices in the area of people management and; 6. data collected from respondents.

Ten face-to-face interviews were conducted with variable duration between the interviewees. The interviews were recorded and later transcribed with the help of the "Express Scribe" program, which is available for free on the Internet.

The data obtained were analyzed according to the content analysis defined by Bardin (2011, p. 48) as the following:

A set of techniques of communication analysis that aims to obtain, through systematic and objective description procedures of the content of their messages, indicators (whether quantitative or not) that allow for the inference of knowledge regarding the production/ reception conditions (inferred variables) of these messages.

Departing from the transcription of the interviews, the resulting content was analyzed to identify the convergence with the categories of analysis outlined a priori, namely, meanings associated with the implementation of the competency-based management model in the organizations, as well as attributes of collective competencies and their sources, as proposed by Retour and Krohmer (2011).

\section{) \\ 6. BRIEF CONSIDERATIONS REGARDING THE IMPLEMENTATION OF THE MODEL IN THE ORGANIZATIONS UNDER STUDY}

\subsection{Secretaria do Tesouro Nacional (STN)}

The STN began implementing the Competency-based Management Model in 2009, forming the Tesouro 2.0 Program, prompted by the convergence of three factors that culminated in the adoption of modernizing measures in the area of people management and consequent implementation of the model in the organization: the institution of the PNDP, the diagnosis of the Organizational Climate and the need to meet the strategic objectives of the organization.

According to the information collected, first, work functions were mapped according to the particularity of each function based on its attributions, requirements, knowledge, skills, and attitudes required to perform the job. 
The mapping of work functions throughout STN was a fundamental input to the first competency-based performance assessment.

The technical competencies, which would include the knowledge and skills related to each job function, were defined according to management units, being each manager responsible for specifying the knowledge and skills required to perform each function. Behavioral competencies were identified according to a behavioral inventory.

Subsequently, the competencies related to behavioral indicators were identified, and both these and the technical competencies were associated with the work functions, allowing for the identification of the desired results for each work function and relation with the employee that would perform it. Approximately a year was needed for the completion of this process and the beginning of the first evaluation cycle of the organization.

The practice of the evaluation cycle associated to the discontinuation of the contract with the consulting firm that implemented it made it necessary to review the cycle. Currently, STN is in the process of designing a system that supports people management and, in addition, is able to supplement the proposed evaluation stage. The management model adopted is being reviewed, especially in relation to the system for the evaluation of performance and the consideration of managerial competencies that are relevant to management.

\subsection{The Federal University of Paraíba (UFPB)}

The UFPB began implementing the Competency-based Management Model in 2012, as a result of the association between the attempt to comply with federal regulations - Decree No. 5707/06 and the Career Plan for Technical-Administrative Positions in Education (Law No. 11091/2005), as well as the need to modernize the area of people management, culminating in the approval of the resolution No. 23/2012 by the University Council (UFBA, 2012), which established the Competency-based Management System - SGPC at the university.

The aforementioned resolution conceptualized the Competency-based Management System as the

[...] system of strategic people management of the Federal University of Paraíba, developed to assist the institution in the professionalization of people management, departing from the identification, development and evaluation of the institutional competencies, organizational environment competencies, and employee competencies [...] 
which would include four subsystems: competency-based performance management, competency-based training, competency-based selection and provision, and staff sizing and movement. Currently, two out of the four subsystems mentioned are in place: the competency-based training and competency-based performance management.

The competencies listed and used in the management system were identified through documentary research regarding the PDI - Institutional Development Plan of the university - in which the following organizational environments dictated by Decree No. 5824/2006 were considered: administration, infrastructure; human, legal and economic sciences; biological sciences; hard and natural sciences; health sciences, agriculture, information, arts, communication and broadcasting; and maritime, fluvial and lacustrine environments.

Until 2015, the university worked with competencies that would be common to the different organizational environments (Learning, Customer service, Participation in management, and Use of information systems) and with individual competencies that should be manifested by the public servant (public interest, interpersonal relationship, team work, and systemic vision).

The majority of respondents considered that the implementation of the model was in its initial stage, since two out of the four subsystems planned, competency-based performance management and competency-based training, had been carried out. In addition, the 2014 Management Report of the UFPB indicates factors that corroborate that with the information provided by the employees and its articulation with the strategic objectives of the institution.

The report indicates, for example, the situation of the Integrated Management System (SIG - UFPB) regarding HR and the modules implemented until 2014 (vacations, training, performance evaluation, requests, and electronic aids and registration). Other actions related to PROGEP performance were cited and would be related to the strategic objective of "consolidating policies for people management, quality of life, health and safety at work and improvement of the work processes of UFPB's employees" (UFPB, 2015, p. 78). In this regard, the following can be mentioned: implementation of the competency-based people management policy and the competency-based performance management policy; the implementation of the training and qualification plan based on the assessment of the needs of competency-based training, and the modernization of people management area through the implementation of the SIG-RH modules. 


\subsection{The Federal University of Pará (UFPA)}

Committed to adapting to the scenario of changes faced by federal higher education institutions and willing to play its strategic role in the Amazon region, UFPA reviewed its vision and mission for the future and built the strategic planning 2011-2015, which culminated in the elaboration of the PDI for the respective period (UFPA, 2011).

Among the outlined strategic objectives, those related to the People and Technology perspective can be directly associated with the Competency-based Management Model, adopted by the institution as one of its management strategies linked to the adequacy to the PNDP, focusing on the continuous development of the public servant.

Although the need to adapt to the PNDP is the background for the implementation of the Competency-based Management Model in UFPA, the factor that prompted its beginning resulted from a project developed by the academic initiative in partnership with PROGEP to map the competencies of the technical-administrative employees of the Belém Campus. The Project was submitted to the call for proposals for projects related to the modernization of public management and was provided with resources from the Action to Promote Development Projects and People Management of the Ministry of Planning, Budget and Management - MPOG. The resource received was converted into scholarships for the students participating in the project.

Currently, the mapping carried out serves as a substrate for training actions. Experiments have been carried out to extend the use of competencies to other areas of people management, such as attraction, selection, and evaluation of performance, still at an embryonic stage according to the interviewees, as well as the mapping of the countryside campi, learning trails, and organizational climate. Such experiments are a consequence of the association between academic development and management, in which PROGEP's own technical-administrative staff, mobilized by sector issues, have proposed to deepen their own thematic development. In fact, the implementation of the model itself is a consequence of such articulation, which generated considerable gains for the university.

\section{DISCUSSION AND RESULTS}

Prompted by the need for modernization of management and by the attempt to comply with the PNDP, the organizations under study faced 
the challenge of implementing a management model meant to be strategic regarding people management, the Competency-based Management Model. The model is considered strategic as it imparts integrative action to people management practices that would be directly linked to the strategic objectives of the institution.

However, the assessment of cases indicates that the unity or integration of such practices is complex and distant, especially in federal higher education institutions. The barriers to be overcome range from the size and complexity of management in a federal university to the lack of understanding of the model and the reasons for its adoption by the employees, including people in high management, to the resistance to change and expressive difficulty toward innovation in management.

With the exception of the STN, which already demonstrates advances towards a greater unification of its practices, the universities presented a focused action, especially in the processes of qualification, as described in Decree No. 5707/06, and are only beginning to outline the transition to other practices.

Far from being a management model, as proposed, organizations clearly still use isolated practices of competency-based management, either because they do not consider the strategic aspect intrinsic to the model, an aspect observed in the three organizations participating in the study, or because of the limitations found in the daily life of the organizations.

In order for the management model to be a strategy of organizational effectiveness, as discussed by Silva and Mello (2011), the development of the employees should occur according to management needs. And although theoretically this aspect seems clear to the interviewees, the organizations also need to adapt themselves to the legal requirements imposed by the government, for they skip stages considered essential to the composition of the adopted model. Thus, the strategic component seems to be compromised in the three organizations analyzed, in which the HR executive profile is prevalent, as proposed by Tanure, Evans and Cançado (2010), according to whom modern policies and practices are used without alignment with the strategy of the organization. Nevertheless, the organizations seem to be on the way to remedy this gap by gradually increasing the articulation of their practices with their respective institutional planning.

It was possible to observe the heterogeneity regarding the implementation of the model, with each institution considering aspects that best suited it to start the process, which seems to be related to the theoretical fragmentation associated with the theme as stated by Brandão and Guimarães (2001) and 
to the lack of guidance that should be provided by the federal government that instituted the PNDP in 2006 but only issued the guidelines for the implementation of competency-based training in 2012, through the Competency-Based Training Management Guide.

In terms of the collective competencies, the perception of the interviewees was not enough to confirm their existence. However, in all organizations, there were examples of collective production that could indicate the possible formation of this type of competency. Nevertheless, Colin and Grasser's (2011) reservation that the mere articulation of the members of a working group to achieve common objectives is not sufficient to verify the formation of a collective competency is important to broaden the discussion on this topic. In Michaux's view (2011), a collective production could indicate the production of a collective competency if it were associated with the gathering of different cognitive and social (cooperative) phenomena, which would favor the capacity to act and react collectively.

It should be emphasized that collective competencies are tacit and depend, for their development, on aspects of context, which the public administration faces difficulties to create. Team dynamics and results, collective learning, sharing of knowledge and experience, and cooperation are hampered by the administrative discontinuities and their previously mentioned effects. The political occupation of management positions creates conflicts and demotivation among team members and their managers, hindering the culture of trust that the production and the sharing of knowledge demand.

However, attributes of collective competencies were reported by respondents, especially common referential and shared language, as shown in Table 1.

\section{(Table 1)}

PERCEPTION OF THE INTERVIEWEES REGARDING THE ATTRIBUTES OF COLLECTIVE COMPETENCIES

\begin{tabular}{clc}
\hline \multicolumn{1}{c}{ ATTRIBUTE } & \multicolumn{1}{c}{ DESCRIPTION } & INTERVIEWEES \\
\hline \multirow{2}{*}{ Common Referential } & Variable according to the working group. & 2 \\
\cline { 2 - 3 } & Noticeable in work groups. & 8 \\
\hline
\end{tabular}




\section{(Table 1)}

\section{PERCEPTION OF THE INTERVIEWEES REGARDING THE ATTRIBUTES OF COLLECTIVE COMPETENCIES (conclusion)}

\begin{tabular}{|c|c|c|}
\hline ATTRIBUTE & DESCRIPTION & INTERVIEWEES \\
\hline \multirow{4}{*}{ Shared Language } & $\begin{array}{l}\text { Evidence of specific vocabulary and technical } \\
\text { terms that facilitate communication. }\end{array}$ & 7 \\
\hline & Could not specify. & 1 \\
\hline & Could not perceive. & 1 \\
\hline & Scarce. & 1 \\
\hline \multirow{5}{*}{ Collective Memory } & $\begin{array}{l}\text { Knowledge management promoted by the } \\
\text { organization. }\end{array}$ & 1 \\
\hline & $\begin{array}{l}\text { Sharing of knowledge varies according to the } \\
\text { individual willingness of the employee. }\end{array}$ & 1 \\
\hline & $\begin{array}{l}\text { Noticeable exchange of knowledge and experience } \\
\text { for the construction of solutions and proposals. }\end{array}$ & 5 \\
\hline & Once in a while realizes the sharing of knowledge. & 1 \\
\hline & Sharing of knowledge encouraged by the manager. & 2 \\
\hline \multirow{5}{*}{ Subjective Engagement } & Variable according to the work group. & 2 \\
\hline & Variable according to employee. & 5 \\
\hline & $\begin{array}{l}\text { Checks engagement, but once in a while considers } \\
\text { management intervention necessary. }\end{array}$ & 1 \\
\hline & $\begin{array}{l}\text { Perceives high level of engagement among the } \\
\text { employees in the working group in which he } \\
\text { participates. }\end{array}$ & 1 \\
\hline & $\begin{array}{l}\text { Generally noticeable, related to the new profile of } \\
\text { employees with higher qualification than the one } \\
\text { required for the position. }\end{array}$ & 1 \\
\hline
\end{tabular}

Source: Elaborated by the authors.

The main aspect cited by the interviewees as being present in the daily work groups was the Common Referential, associated with a shared understanding of the group's objectives and the means to reach them. Aspects such as institutional planning and holding of meetings were cited as facilitators in this process, being the meetings placed by Bonotto and Bitencourt (2006) as a stimulus to the development of collective competency. 
The shared language attribute can also be highlighted, with the presence of specific vocabulary words and technical terms that facilitate communication in work groups, allowing for the development of common operative language, as argued by Retour and Krohmer (2011).

The aspect that generated the most objections on the part of the interviewees refers to the Subjective Engagement, since it is about the way the employees deal with the work and their commitment with it.

Regarding the sources of competencies, Table 2 summarizes the interviewees' perceptions regarding aspects related to individuals: individual competencies, affective interactions, informal relationships and cooperation.

\section{(Table 2)}

INTERVIEWEES' PERCEPTION OF INDIVIDUAL SOURCES OF COLLECTIVE COMPETENCIES

\begin{tabular}{lll}
\hline \multicolumn{1}{c}{ SOURCE } & \multicolumn{1}{c}{ DESCRIPTION } & INTERVIEWEES \\
\hline \multirow{3}{*}{ Individual competencies } & $\begin{array}{l}\text { They usually place individual } \\
\text { competencies at the service of the } \\
\text { organization. }\end{array}$ & 7 \\
\cline { 2 - 3 } $\begin{array}{l}\text { Variable according to employee. } \\
\text { relationships }\end{array}$ & $\begin{array}{l}\text { Promising in the development of the } \\
\text { work. }\end{array}$ & 2 \\
\hline & $\begin{array}{l}\text { Affective interactions committed to the } \\
\text { work group to which they belong. }\end{array}$ & 2 \\
\hline \multirow{3}{*}{ Cooperation } & \begin{tabular}{l} 
Present in work groups. \\
\cline { 2 - 3 }
\end{tabular} & $\begin{array}{l}\text { Variable according to the individual } \\
\text { willingness of employee. }\end{array}$ \\
\cline { 2 - 3 } & Variable according to the work group. & 2 \\
\hline
\end{tabular}

Source: Elaborated by the authors.

Respondents reported the presence of sources related to individuals, with emphasis on affective relationships and establishment of informal interactions that were considered relevant to the composition of a promising working environment for the community and constitution of a sense of community as approached by Retour and Krohmer (2011).

Regarding organizational aspects, Table 3 summarizes the interviewees' perceptions and, although it is possible to identify the concern of the organizations with the construction of effective work groups, there is a 
diversity of postures regarding the existence of formal aspects that contributes to the commitment on the part of the employees.

\section{(Table 3) \\ INTERVIEWEES' PERCEPTION OF ORGANIZATIONAL SOURCES OF COLLECTIVE COMPETENCIES}

\begin{tabular}{|c|c|c|}
\hline SOURCE & DESCRIPTION & INTERVIEWEES \\
\hline \multirow{3}{*}{$\begin{array}{l}\text { Configuration of work } \\
\text { groups }\end{array}$} & Concern with creating effective work groups. & 8 \\
\hline & Faulty; focus on replacement of employees. & 1 \\
\hline & No answer. & 1 \\
\hline \multirow{7}{*}{ Formal interactions } & $\begin{array}{l}\text { Absence of a formal structure conducive to } \\
\text { employees' commitment. }\end{array}$ & 2 \\
\hline & $\begin{array}{l}\text { Knowledge of employees' profiles and use of their } \\
\text { competencies. }\end{array}$ & 2 \\
\hline & $\begin{array}{l}\text { An approach to put work groups together, based on } \\
\text { individual employee's willingness. }\end{array}$ & 1 \\
\hline & $\begin{array}{l}\text { Therapeutic management operation; intervention } \\
\text { when identifying problems. }\end{array}$ & 1 \\
\hline & $\begin{array}{l}\text { Layout (physical configuration of employees leading } \\
\text { to interaction). }\end{array}$ & 1 \\
\hline & Manager role. & 2 \\
\hline & No answer. & 1 \\
\hline \multirow{3}{*}{ Administration style } & Relative autonomy. & 5 \\
\hline & Room for autonomy. & 3 \\
\hline & Presence of autonomy. & 2 \\
\hline $\begin{array}{l}\text { Factors associated } \\
\text { with People } \\
\text { Management that } \\
\text { prompt Collective } \\
\text { Competencies }\end{array}$ & Specific actions. & 10 \\
\hline
\end{tabular}

Source: Elaborated by the authors.

The factors conducive to collective competencies associated to the performance of the people management area were marked by specific actions in all organizations because people management practices still have very limited internal articulation, and no priority is placed on the development of variables that may directly foster collective actions. 


\section{CONCLUSIONS}

The analysis of the results revealed that the focus on individual competencies and disregard for the collective ones tend to prevail in institutional management practices, despite the fact that they undertake actions that could contribute to the development of attributes and/or sources of creation of collective competencies.

The results of the analyses confirmed that the models used by the public organizations focus on the individual; it was not possible to identify the use and management of collective competencies. These results demonstrate that organizations use competency-based management in a limited way, and when they do use it they are merely trying to comply with the requirements of the legislation that mandates its use in public administration rather than considering competency-based management as a tool for the collective development of work.

The emphasis on individual competencies could indicate reductionism in the management model or the use of tools and techniques that prove to be isolated and incoherent with the strategic conception necessary to the management model. In addition, Colin and Grasser (2011) introduce relevant theoretical concern when questioning whether the emphasis attributed to the current competency referential, reduced to individual competencies, would conflict with collective competencies, and they mention Allouche and Gilbert (as cited in Colin \& Grasser, 2011) by pointing out the contradiction between the individualization of human resources management and the emphasis on the development of social capital which would, in turn, require a collective management style.

The emphasis on individual competencies may also indicate the marginalization of collective competencies that emerge from collective work practices, compromising the scope of the model and the possible strategic differential, if they were considered and fostered by the organization.

When considering the dimensions of competency in the literature, it was possible to see the specific reference to the knowledge, skills and attitudes that the employees should present and develop for the adequate performance of their duties, which is directly related to their positions and careers.

With regard to the proposal of this study, which is meant to observe how management practices identify, consider and articulate with organizational and collective competencies, it was not possible to establish a direct relationship 
between these parts due to the fact that organizational competencies do not present an inherent strategic trait, and the collective competencies are not actively managed, as it is possible to assume from the data obtained.

Nonetheless, when considering the attributes of collective competencies and their sources of creation, there were occasional specific actions performed by respective areas of people management that would possibly provide basis for the creation of a fertile ground for future development of collective competencies.

These results reinforce the difficulties faced by the Brazilian public administration due to the coexistence of the traditional bureaucratic model with premises defended by the managerial model of public administration.

It is important to highlight, however, the limitations of this study, considering that the area responsible for implementing the model in the organization was the provider of the information about the model and functioning of the work groups, possibly compromising the impartiality of the information provided. Given that, the managers of the area were the respondents of the research questions. Their answers may have presented certain bias in order to positively evaluate the processes under investigation. Additionally, the number of interviews may be considered reduced and restricted to the area of people management, due to the reality faced by each institution.

For a greater understanding of the subject, additional studies must be carried out, including the views of professionals from different sectors and hierarchical levels of the institution and the observation of work groups, which will allow for the access to variables, not considered in this study, that may facilitate the identification of collective competencies.

It should be noted that, when considering such a phenomenon, the competency-based management model could be enriched in its practical application, promoting real benefits for organizations, extrapolating the dimension of discourse and permeating the day-to-day of organizational operations, which would allow for the constitution of collective work.

\section{REFERENCES}

Amaral, H. K. (2006). Desenvolvimento de competências de servidores na administração pública brasileira. Revista do Serviço Público Brasília, 57(4), 549-563. Retrieved from http://repositorio.enap.gov.br/handle/1/1422

Bardin, L. (2011). Análise de conteúdo. São Paulo: Edições 70. 
Bergue, S. T. (2014). Gestão estratégica de pessoas no setor público. São Paulo: Atlas. Bonotto, F., \& Bitencourt, C. C. (2006). Os elementos das competências coletivas em grupos de trabalho: A experiência da COPESUL. Encontro Anual da ANPAD. Salvador, BA, Brazil, 30. Retrieved from http://www.anpad.org. br/enanpad/2006/dwn/enanpad2006-eorb-1882.pdf

Boreham, N. (2004). A theory of collective competence: Challenging the neo--liberal individualisation of performance at work. British Journal of Educational Studies, 52(1), 5-17. doi 10.1111/j.1467-8527.2004.00251.x

Brandão, H. P., \& Guimarães, T. A. (2001). Gestão de competências e gestão de desempenho: Tecnologias distintas ou instrumentos de um mesmo constructo. Revista de Administração de Empresas, 41(1), 8-15. doi 10.1590/ S0034-75902001000100002

Carbone, P. P., Brandão, H. P., Leite, J. B. D., \& Vilhena, R. M. P. (2009). Gestão por competências e gestão do conhecimento (3 ed.). Rio de Janeiro, RJ: FGV. Colin, T., \& Grasser, B. (2011). Das competências individuais à competência coletiva: Contribuições da aprendizagem em um serviço de emergência hospitalar. In D. Retour, T. Picq, C. Defélix, \& R. Ruas. Competências coletivas: No limiar da estratégia (pp. 79-98). Porto Alegre: Bookman.

Comini, G. M., Konuma, C. M., \& Santos, A. L. (2008). Sistema de gestão de pessoas por competências: Um olhar crítico para a dimensão do desenvolvimento individual. Gestão \& Regionalidade, 24(69), 6-18. Retrieved from http://www.redalyc.org/html/1334/133417322001/

D’Araújo, M. C. (2007). Governo Lula: Contornos sociais e políticos da elite do poder. Rio de Janeiro: CPDOC/FGV.

Decreto n. 5707, 23 de fevereiro de 2006. (2006). Institui a política e as diretrizes para o desenvolvimento de pessoal da administração pública federal direta, autárquica e fundacional, e regulamenta dispositivos da Lei n. 8.112, de 11 de dezembro de 1990. Diário Oficial da União, Casa Civil, Brasil. Retrieved from http://www.planalto.gov.br/ccivil_03/_Ato2004-2006/2006/Decreto/ D5707.htm

Decreto n. 5824, 29 de junho de 2006. (2006). Estabelece os procedimentos para a concessão do incentivo à qualificação e para a efetivação do enquadramento por nível de capacitação dos servidores integrantes do plano de carreira dos cargos técnico-administrativos em educação, instituído pela Lei n. 11.091, de 12 de janeiro de 2005. Diário Oficial da União, Casa Civil, Brasil. Retrieved from http://www.planalto.gov.br/ccivil_03/_Ato2004-2006/2006/Decreto/ D5824.htm 
Defelix, C., Le Boulaire, M., Monties, V., \& Picq, T. (2014) La compétence collective dans le contexte de la globalisation du management: Retrouver le lien avec la performance. @GRH, 11(2), 31-50. doi 10.3917/grh.142.0031

Fernandes, B. R. (2013). Gestão estratégica de pessoas com foco em competências. Rio de Janeiro, RJ: Elsevier.

Fonseca, D. R., Meneses, P. P. M., Silva Filho, A. I., \& Campos, N. G. (2013). Autonomia para gestão estratégica de pessoas no setor público federal: Perspectivas de análise e agenda de pesquisa. RAP, 47(6), 1451-1475. Retrieved from http://bibliotecadigital.fgv.br/ojs/index.php/rap/article/view/13982

Fontoura, D. S., Avila, V. P., Corsetti, R., \& Ruas, R. L. (2011). Competências coletivas: uma tentativa de aproximação do conceito e identificação em uma organização do ramo editorial. Encontro de Gestão de Pessoas e Relações de Trabalho (EnGPR), João Pessoa, PB, Brazil, 3. Retrieved from http://www. anpad.org.br/admin/pdf/EnGPR340.pdf

Frohm, C. (2002). Collective competence in an interdisciplinary project context. Sweden: UniTryck.

Giansante, C. C. B. (2013). Relações entre características dos integrantes de equipes, competências coletivas e desempenho coletivo (Master's thesis). Universidade Metodista de São Paulo, São Bernardo do Campo, SP, Brazil. Retrieved from http://tede.metodista.br/jspui/handle/tede/38

Grimand, A. (2011). Das competências individuais às competências estratégicas: Uma experiência de modelagem das estratégias concorrenciais com base na gestão de recursos humanos. In D. Retour, T. Picq, C. Defélix, \& R. Ruas, Competências coletivas: no limiar da estratégia (pp. 23-44). Porto Alegre: Bookman.

Guimarães, T. A. (2000). A nova administração pública e a abordagem da competência. RAP, 34(3), 125-140. Retrieved from http://repositorio.unb. $\mathrm{br} / \mathrm{handle} / 10482 / 15980$.

Le Boterf, G. (2003). Desenvolvendo a competência de profissionais. Porto Alegre, RS: Artmed.

Lei n. 11091, 12 de janeiro de 2005. (2005). Dispõe sobre a estruturação do Plano de Carreira dos Cargos Técnico-Administrativos em Educação, no âmbito das Instituições Federais de Ensino vinculadas ao Ministério da Educação, e dá outras providências. Diário Oficial da União, Casa Civil, Brasil. Retrieved from http://www.planalto.gov.br/ccivil_03/_ato20042006/2005/lei/111091.htm

Lima, J. O., \& Silva, A. B. (2015). Determinantes do desenvolvimento de competências coletivas na gestão de pessoas. Revista de Administração 
Mackenzie, 15(16), 41-67. doi 10.1590/1678-69712015/administracao. v16n5p41-67

Michaux, V. (2011). Articular as competências individual, coletiva, organizacional e estratégica: Esclarecendo a teoria dos recursos e do capital social. In D. Retour, T. Picq, C. Defélix, \& R. Ruas, Competências coletivas: no limiar da estratégia (pp. 1-22). Porto Alegre, RS: Bookman.

Monteiro, L. M. (2013). Reforma da administração pública e carreiras de Estado: o caso dos especialistas em políticas públicas e gestão governamental no Poder Executivo federal. Revista de Administração Pública, 47(5), 11171143. doi 10.1590/S0034-76122013000500003

Nelson, R., \& Winter, S. (1982). An evolutionary theory of economic change. Cambridge: Harvard University Press. Retrieved from http://inctpped. ie.ufrj.br/spiderweb/pdf_2/Dosi_1_An_evolutionary-theory-of_economic_ change.pdf

Pauvers, B., \& Schieb-bienfait, N. (2011). Competências individuais e coletivas no centro da estratégia: Um estudo de caso longitudinal em uma empresa cooperativa de construção civil. In D. Retour, T. Picq, C. Defélix, \& R. Ruas, Competências coletivas: no limiar da estratégia (pp. 127-152). Porto Alegre, RS: Bookman.

Prahalad, C. K., \& Hamel, G. (1990). The core competence of the corporation. Havard Business Review, May/June, 78-90. Retrieved from https://www. profrandes.com.br/userfiles/37e2f78e93b640608ec17b8de1b6d4b5.pdf

Pires, J. C. S., \& Macêdo, K. B. (2006). Cultura organizacional em organizações públicas no Brasil. Revista de Administração Pública, 40(1), 81-104. doi 10.1590/ S0034-76122006000100005

Retour, D., \& Krohmer, C. (2011). A competência coletiva: uma relação chave na gestão de competências. In D. Retour, T. Picq, C. Defélix, \& R. Ruas, Competências coletivas: No limiar da estratégia (pp. 45-78). Porto Alegre, RS: Bookman.

Ruas, R. (2005). Gestão por competências: Uma contribuição à estratégia das organizações. In R. Ruas, C. S. Antonello, \& L. H. Boff (Orgs.). Os novos horizontes da gestão: Aprendizagem organizacional e competências (pp. 34-54). Porto Alegre, RS: Bookman.

Sandberg, J. (1994). Human competence at work: An interpretative approach. Suécia: Grafikerna I Kungälv. Retrieved from http://hdl.handle.net/2077/13996 Schikmann, R. (2010). Gestão estratégica de pessoas: Bases para a concepção do curso de especialização em gestão de pessoas no serviço público. In M. J. Pantoja, M. R. S. Camões, \& S. T. Bergue (Orgs.). Gestão de pessoas: Bases teóricas e experiências no setor público. Brasília: ENAP. 
Silva, F. M. (2013). As práticas de gestão de recursos humanos e o processo de identificação de competências coletivas: Um estudo de caso na área de gestão de pessoas do centro administrativo do SICREDI (Doctoral dissertation). Universidade Federal do Rio Grande do Sul, Porto Alegre, RS, BraZil. Retrieved from http://hdl.handle.net/10183/72771

Silva, F. M., \& Mello, S. P. T. (2011). A noção de competência na gestão de pessoas: Reflexões acerca do setor público. Revista do Serviço Público, 62 (2), 167183. Retrieved from http://repositorio.enap.gov.br/handle/1/1608

Silva, F. M., \& Ruas, R. L. (2016). Competências coletivas: considerações acerca de sua formação e desenvolvimento. Revista Eletrônica de Administração, 22 (1), 252-278. doi 10.1590/1413-2311.0102015.54938

Siqueira, M. V. S. (2006). Gestão de pessoas e discurso organizacional: Crítica à relação indivíduo-empresa nas organizações contemporâneas. Goiânia: UCG.

Tanure, B., Evans, P., \& Cançado, V. L. (2010). As quatro faces do RH: Analisando a performance da gestão de recursos humanos em empresas no brasil. Revista de Administração Contemporânea, 14(4), 494-614. doi 10.1590/ S1415-65552010000400003

Ubeda, C. L. (2003). A gestão de competências em uma empresa de pesquisa e desenvolvimento (Master's thesis). Universidade de São Paulo, São Carlos, SP, Brasil. doi 10.11606/D.18.2003.tde-11092004-165136

UFPA. (2011). Plano de Desenvolvimento Institucional 2011 - 2015. Belém, PA. UFPB. (2015). Relatório de Gestão 2014. João Pessoa, PB.

UFPB. (2012). Resolução n. 23/2012, de 09 de novembro de 2012. Aprova a implantação do Sistema de Gestão de Pessoas por Competências (SGPC) da UFPB. ConsUni, João Pessoa, PB.

Zarifian, P. (2001). Objetivo competência: Por uma nova lógica. São Paulo, SP: Atlas.

\section{$\int$ ABOUT THE AUTHORS}

KELLY WEIRES RODRIGUES SOARES AVELINO

Master degree in Administration from the Faculty of Business Administration and Accounting, Universidade Federal Fluminense (UFF).

$\mathrm{PhD}$ student for the Brazilian School of Public and Business Administration,

Fundação Getúlio Vargas (FGV).

Rua Jornalista Orlando Dantas, 30 - Botafogo - Rio de Janeiro - RJ - Brasil - CEP 22231-010

E-mail: kellyweires@gmail.com 


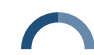

Kelly Weires Rodrigues Soares Avelino, Denise Medeiros Ribeiro Salles, Isabel de Sá Affonso da Costa

\section{DENISE MEDEIROS RIBEIRO SALLES}

$\mathrm{PhD}$ in Administration from the Brazilian School of Public and Business Administration, Fundação Getúlio Vargas (FGV).

Professor at the Faculty of Business Administration and Accounting, Universidade Federal Fluminense (UFF).

Rua Mário Santos Braga, 30 - Centro - Niterói - RJ - Brasil - CEP 24020-140

E-mail: denisesalles@id.uff.br

\section{ISABEL DE SÁ AFFONSO DA COSTA}

$\mathrm{PhD}$ in Administration from the Brazilian School of Public and Business Administration, Fundação Getúlio Vargas (FGV).

Professor at the Faculty of Administration,

Universidade Estácio de Sá.

Av. Presidente Vargas, 642, Centro - Rio de Janeiro - RJ- Brasil - CEP 20071-001

E-mail: isabel.costa@estacio.br 